\title{
Investigation of a Solar Polygeneration System for a Multi- Storey Residential Building-Dynamic Simulation and Performance Analysis
}

\author{
Mohammed Missoum ${ }^{a^{*}}$ and Larbi Loukarfi ${ }^{\mathrm{b}}$ \\ aDepartment of Civil Engineering, Faculty of Technology, University Center of Morceli Abdellah, , Tipaza, Algeria \\ ${ }^{b}$ Department of Mechanic Engineering, Faculty of Technology, University of Hassiba Ben Bouali, Chlef, Algeria
}

\begin{abstract}
In the present study, the performance of a novel configuration of a solar polygeneration system for a multi-family residential building is investigated using dynamic simulation models. The system consists in Building Integrated PhotoVoltaic/Thermal (BIPVT) collectors, a water-to-water reversible heat pump and an adsorption chiller. The solar system will ensure space heating in winter, space cooling in summer and domestic hot water and electricity all over the year for a multi-storey building located in Algiers (Algeria). In the case of insufficient solar energy, the system is equipped with a gas-fired heater for auxiliary heat production, whereas the auxiliary electricity is supplied by the national grid. First, the simulation models of the solar system components and the building were described and developed in TRNSYS environment. Then, an energy-economic model based on the calculation of the primary energy consumption, the primary energy saving, the simple payback period and the electrical and thermal solar fractions, was carried-out. Finally, the system performance in terms of daily, monthly and yearly results was investigated and compared to the performance of a conventional energy system commonly used in Algerian buildings. The simulation results indicate that the solar collectors have the potential to cover more than $56 \%$ and $72 \%$ of the yearly heat and electricity requirements, respectively. The total primary energy saving achieved by the solar system with respect to the conventional one is $37.1 \mathrm{MWh} / \mathrm{y}$, which represents $39 \%$ of the energy consumption of the conventional system. However, the economic feasibility of proposed solar system is difficult to be achieved due to the high initial cost of the solar collectors. Indeed, the obtained simple payback period is 55.40 years. Moreover, a sensitivity analysis has been performed aiming at studying the effect of various technical and economical parameters on the system performance. The analysis shows that the energetic as well as economic performances of the system are strongly influenced by the photovoltaic/thermal filed area, the system cost and the unitary cost of electricity. The system becomes economically profitable when the system cost is $400 € / \mathrm{m}^{2}$ and the electricity cost is $0.12 € / \mathrm{kWh}$. Additionally, the system performance is better in climate conditions where solar potential and building energy requirements are important.
\end{abstract}

Keywords: solar polygeneration system, solar assisted heat pump, adsorption chiller, energy and economic performances, primary energy saving, simple payback period.

Article History: Received: $13^{\text {th }}$ November 2020; Revised: $22^{\text {nd }}$ January 2021; Accepted: $10^{\text {th }}$ February 2021 ; Available online: $18^{\text {th }}$ Feb 2021 How to Cite This Article: Missoum, M. and Loukarfi, L.(2021) Investigation of a Solar Polygeneration System for a Multi-Storey Residential Building-Dynamic Simulation and Performance Analysis. Int. Journal of Renewable Energy Development, 10(3), 445-458 https://doi.org/10.14710/ijred.2021.34423

\section{Introduction}

In the recent years, the use of renewable energy systems instead of conventional fossil fuel-based energy systems is regarded as a promising solution for reducing the growing energy demand and greenhouse gases emissions, particularly in building sector, which accounts for, respectively, more than $40 \%$ and $30 \%$ of total energy enduse and greenhouse gas emissions (Costa et al., 2013). Of particular interest are solar polygeneration systems, which use solar irradiation for producing multiple useful energy outputs like electricity and heat efficiently (Kasaeian et al., 2020). Among the available solar technologies, hybrid thermal energy and electricity collectors (i.e. PhotoVoltaic/Thermal (PVT) collectors) are promising due to their several advantages, namely: the simultaneous production of heat and electricity which improves strongly the overall energy efficiency of the solar system; low investment cost; and easy operating conditions and maintenance (Brahim \& Jemni, 2017).

For building application, various configurations can be obtained by combining PVT collectors and different energy conversion devices (Calise et al., 2018). The thermal energy output from PVT collectors can be used directly for heating the building and domestic hot water production, or/and to drive an absorption (Alobaida et al., 2017), adsorption (Papoutsis et al., 2017), chillers and desiccant machines (Guo et al., 2017) for meeting the building cooling requirements. Moreover, PVT collectors can be easily used to drive direct (Fraga et al., 2017; Awani et al., 2015),), or indirect (Plytaria et al., 2018) solar assisted heat pumps (SAHP) due to their low operating temperature. An extensive review about the combination of PVT collectors with heat pumps (PVT-HP systems) was performed by (Vaishak\& Bhale, 2019).

*Corresponding authors: masf@hotmail.fr 
Solar polygeneration systems with stand-alone PVT collectors for building application have been investigated in several studies (Buonomano et al., 2019; Calise et al., 2012),); Sancho, 2014). The system is always equipped with an adsorption chiller or/and solar assisted heat pump due to their low operating temperature (Calise et al., 2016 ; Ramos et al., 2017). Furthermore, the performance of the system could be enhanced by adding an electrical storage system (Calise et al., 2017).

In the last decade, several studies focused on the integration of solar power and heat collectors, such as Building Integrated PhotoVoltaic-Thermal (BIPVT) collectors, within the building elements (Shan et al., 2014). In comparison to a Building Integrated Photovoltaic (BIPV) system, the performance of BIPVT system has significant potential for wide use in buildings since a certain amount of thermal energy is produced (Agrawal \&Tiwari, 2010; Debbarmaa et al., 2017). (Calise et al. 2020) studied and compared the energetic and economic performances of two different polygeneration systems. The first system is based on BIPV collectors, whereas the second one includes Building Integrated hybrid BIPVT collectors. For both systems, the electricity produced by solar collectors is used in parallel with that provided by small size wind turbines to drive a reversible air-to-water heat pump. A case study of a hotel building is considered. The two systems performances were investigated by means of a dynamic simulation model in TRNSYS. It was found that the best primary energy saving is obtained in the BIPVT case $(73 \%)$ vs. the BIPV system (70\%). However, the system based on BIPV collectors is more economically profitable than the BIPVT one. A simple payback period (SPB) of about 4.5 years is achieved by the system with BIPV system. From environmental point of view, the difference about the avoided $\mathrm{CO}_{2}$ emissions is not significant between the two studied systems. The obtained results from parametric analysis showed that the number and size of wind turbines affect strongly the economic performance of the system.

The major advantage of BIPVT collectors, with respect to stand-alone PVT one, is their potential to reduce passively and actively the overall building energy demand (Lamnatou et al., 2015). (Buonomano et al. 2015) investigated the performance of different residential buildings integrating BIPVT collectors for simultaneous production of thermal energy, electricity and domestic hot water. The PVT collectors are integrated in the building roof and/or south façade or installed on a land adjacent to a typical multi-floors residential building. A building without solar collectors is considered as a reference building. Electrical heat pumps and a gas fired boiler are used as backup systems. The objective of the study was to determine the passive as well as active influences of the integration of solar technologies within the building on its energy requirements. The study was conducted for various European weather zones. Dynamic simulation models are used to assess and compare the performances of proposed systems. The simulation results show that the variation of the building envelope capacitance affects slightly the energy performance of the building-plant system. However, for all considered weather zones, considerable primary energy savings are achieved by the different considered building-plant configurations, with respect to the reference one. Further, the integration of PVT panels in both roof and south façade of the building leads to the highest energy saving. The best performances were achieved in weather zones with low heating degree days (HDD). In fact, the highest PES (89\%) is achieved in Almeria. Regarding economical performance, simple payback periods ranging between 11 and 20 years were obtained for the all analyzed building-plan systems and weather zones. Finally, SPBs achieved by building PVT panels integrated in only-roof are lower than those obtained by roof and façade BIPVT collectors.

BIPVT collectors produce low-temperature useful heat, which may be utilized directly for satisfying space heating and domestic hot water (DHW) (Li et al., 2015; Buker et al., 2015). In another work, (Buonomano et al. 2019) presented an exergetic and techno-economic analysis of a BIPVT system, coupled with an electricity storage system (ESS) in order to overcome the problem of solar energy fluctuations and intermittency. The system is designed to supply space heating via a radian floor, domestic hot water and electricity for a high-rise building. Auxiliary systems, including air-to-water heat pumps for space heating and cooling and a condensing boiler to produce DHW, are considered in this study. The auxiliary electrical energy is supplied by the national grid. The BIPVT system performance is compared with a conventional building (without PVT system, ESS and radian floor) for different European whether zones. The transient behavior of the BIPVT system is predicted by TRNSYS tool. The results show that significant reductions of thermal and electrical energy demands required from auxiliary systems and the national grid, respectively, are achieved. The average exergetic efficiencies of ESS and the condensing boiler one are about $90 \%$ and $2 \%$, respectively. The proposed system is economically viable with a SPB of about 4 years. The highest destroyed exergy of BIPVT occurs in Larnaca (150 $\mathrm{MWh}$ /year), whereas the better BIPVT collectors exergetic efficiency is $8.8 \%$ for Belfast.

The thermal energy produced by BIPVT collectors can also satisfy space cooling through heat-driven machines, such as adsorption chiller $\left(45^{\circ} \mathrm{C}-65^{\circ} \mathrm{C}\right)$. Indeed, the same authors (Buonomano et al., 2017) enhanced the above mentioned polygeneration system layout by adding an adsorption chiller for space cooling purpose. The system is investigated from energy, economic and environmental points of view. The system was applied on multi-floor office building for different Italian climate conditions. The produced electricity is used to satisfy the building needs and the extra-production is delivered to the grid or stored in lead-acid batteries. It was found that the primary energy saving ranges between $58.5 \%-68.8 \%$ and the SPB ranges between 10.6-11.3 years and the equivalent carbon dioxide avoided emissions range between $76.3-90.2 \%$.

In this paper, a novel configuration of a polygeneration system is investigated from both energetic and economic points of view. The proposed system is based on the combination of BIPVT solar collectors with two lowtemperature heat-driven devices, an indirect water-towater heat pump and an adsorption chiller. According to the literature review, this solar system configuration has never been studied. The system will supply space heating and cooling, domestic hot water and electricity for a typical multi-family building in Algeria. A dynamic simulation model of the solar system is developed using TRNSYS tool. An efficient system control is integrated in the model for the proper functioning of the solar system. 


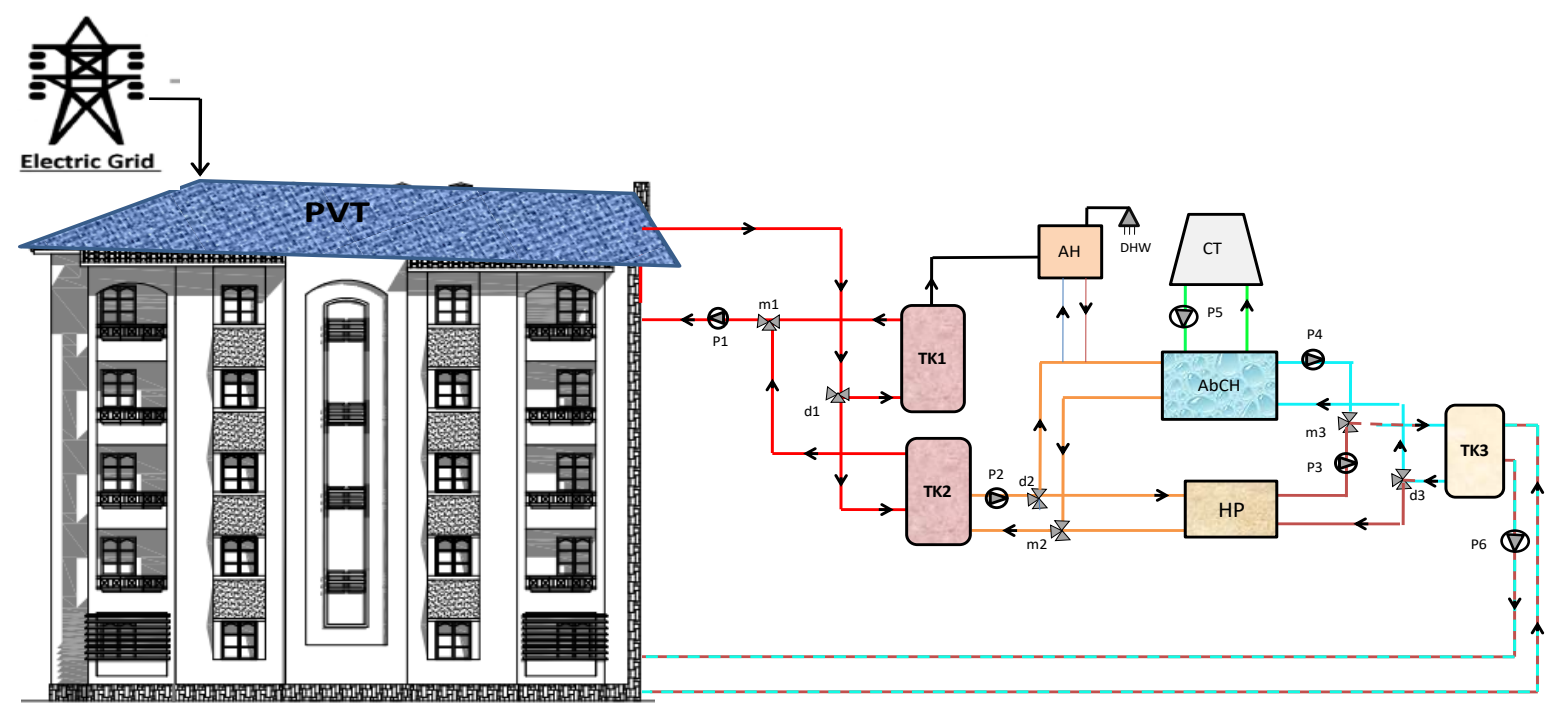

Fig. 1. Schematic layouts of the studied solar system

The performance of the proposed solar system is investigated with respect to a reference system using fossil fuels and commonly used in Algerian buildings. Furthermore, a sensitivity analysis is also carried out in order to determine the effect of various technical and economical parameters on the performance of the solar system, such as BIPVT area, system cost, volume tank, unitary cost of fossil fuels and weather climate conditions.

\section{System description}

The system studied in this work is designed to convert the solar irradiation into both thermal and electrical energies for covering a great part of the energy demands of a multi-family building located in (Algiers) Algeria. The later is considered as a reference building. The building was built in the framework of a pilot project called ECOBAT launched by the government with the aim to enhance the energy efficiency in building sector (Bahria et al, 2016), which is responsible for more than $35 \%$ of the final energy consumption (MEM, 2019).

The system heats the building in winter and cools it in summer and produces domestic hot water (DHW) and electricity all the year around. The building brings the electrical energy from the utility grid in case of absence or intermittent solar radiation. Meanwhile, a gas-fired auxiliary heater is used to complete the thermal energy demand.

The considered solar system layout consists of Building Integrated Photovoltaic/Thermal (BIPVT) collectors, three inertial storage tanks (TK1, TK2 and TK3), five fixedvolume pumps (P1-P6), an adsorption chiller (AdCH), a water-to-water heat pump (HP) and a gas-fired auxiliary heater (AH), in addition to several others secondary components such as valves, pipes, mixers and diverters.

The electrical energy output from the BIPVT system is used primarily to satisfy the electric demand of the system (heat pump, adsorption chiller and electric pumps). The excess of electrical energy could be consumed by building electric equipments (such as lighting and electric appliance). The schematic drawn of the system under investigation coupled to the considered building is presented in Figure 1.

The solar polygeneration system (PS) is dynamically simulated using TRNSYS software. For the proper functioning of the solar system, an effective control strategy was applied by using several types of controllers (such as on/off controllers, thermostats, and aquastats.etc.).

The operating mode of the system is changed automatically, depending on the building needs and seasons. The heat provided by BIPVT collectors is transported to TK1, where it is used to supply the HP in winter and a part of the heat required by $\mathrm{AdCH}$ in summer. The surplus of produced heat is delivered to TK2 for the DHW preparation. In other words, when TK1 average temperature is within fixed range $\left(25-30^{\circ} \mathrm{C}\right)$ in winter or $\left(60-65^{\circ} \mathrm{C}\right)$ in summer, BIPVT collectors deliver heat to TK2 using P1. The pump P1 of the solar loop is turned on only when there is sufficient solar radiation. When the heat produced by solar collectors is insufficient in summer, a gas-fired auxiliary heater is activated to add the thermal energy required by the $\mathrm{AdCH}$.

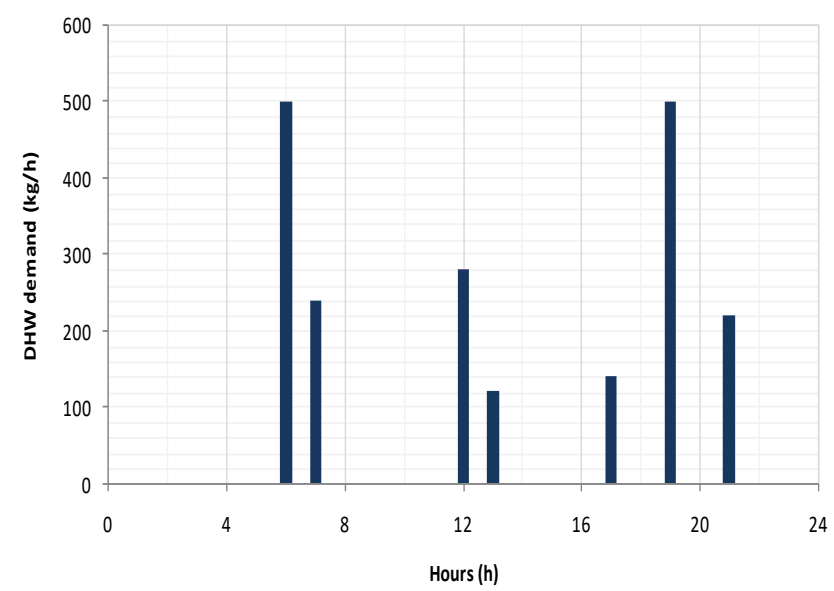

Fig 2. Daily profile of DHW demand of the building 


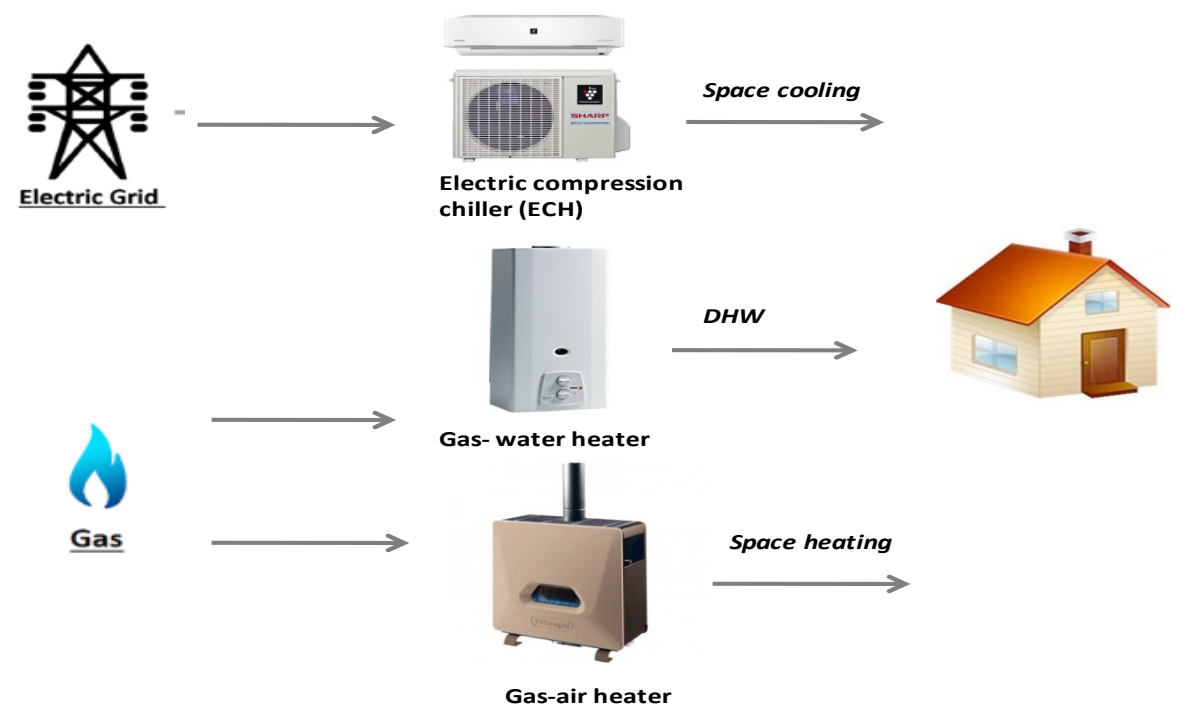

Fig. 3 Schematic layouts of the reference system

Table1.

Models of the system components used in the simulation

\begin{tabular}{lll}
\hline Component & Type & Comment \\
\hline Building & Type 56 & Multi-zone building model \\
BIPVT collectors & Type 650 & Interact with Type 56 model \\
Adsorption chiller & Type 655 & Performance data based \\
Cooling tower & Type 51 & Closed-circuit cooling tower \\
Reversible heat pump & Type 668 & Performance data based \\
Auxiliary heater & Type 6 & Gas-fired auxiliary heater \\
Hot/Cold water storage tank & Type 60 & Detailed fluid storage tank \\
Circulation pump & Type 114 & Fixed speed pump \\
\hline
\end{tabular}

In heating season, $\mathrm{P} 2$ is used to circulate the hot water between TK1 and the HP, which produces thermal energy needed to keep TK3 temperature in the range $\left(45-50^{\circ} \mathrm{C}\right)$. When the temperature in the building drops below $20^{\circ} \mathrm{C}$, pump (P3) is turned on and hot water is pumped through the building via a heating floor. In summer, chilled water, drawn by pump P3, is delivered to TK3 to conserve the later within the required temperature range $\left(12-15^{\circ} \mathrm{C}\right)$.

When the building temperature exceeds the cooling set point temperature $\left(25^{\circ} \mathrm{C}\right), \mathrm{P} 6$ is turned on and cold water is supplied to the building floor. The heat rejected from the adsorption chiller is transferred to the ambient by a cooling tower, via P5. When the DHW is required, the hot water is delivered directly from the storage tank TK2 to the user. Another auxiliary heater is connected to TK2 to supply any deficit heat requirements. A tempering valve is used to ensure DHW temperature at around $45^{\circ} \mathrm{C}$ at the user-end.

The daily profile for DHW demand of the building occupants is obtained by considering a request of 50 1/person and is reported in Figure 2. In Algeria, space heating and cooling are usually provided separately, using gas-fired heaters and air-conditioning units, respectively, as shown in Figure 3. In this paper, in order to show the advantage of the proposed solar system, its performance is investigated with respect to a reference system. In this system, the electricity from the utility grid is used to drive an electric compression chiller (ECH) for space cooling and natural gas is used to power a gas-fired air heater for space heating. At same time, the natural gas is used to power a gas-fired water heater to supply the required DHW for the building occupants.

\section{TRNSYS model}

The solar system under investigation is simulated using TRNSYS software. It is one of the widely used transient simulation tool in the design of dynamic energy systems and their interaction with buildings (TRNSYS, 2006). The mathematical models of the system components are displayed in Table 1.

\subsection{Building}

The reference building energy demands are estimated using Type 56 component of TRNSYS. The zone is described using this component through the introduction of a set of parameters and inputs. Characteristics of walls, windows, roof, and floors, internal gains, and air change rate should be specified. Properties of different elements of the building envelope (thermal conductivity, transmittance, thickness, etc.) are either introduced. The U-values of the opaque building envelope are presented in Table 2 . 
Table 2

U-value of the building envelope

\begin{tabular}{llll}
\hline Element & Layers & Thickness $(\mathbf{m})$ & U-value (W/m $\mathbf{2} . \mathbf{K})$ \\
\hline Roof & Tile & 0.02 & 5.88 \\
High slab & Fermacell & 0.01 & \\
& OSB & 0.02 & 0.39 \\
& Air space & 0.15 & \\
OSB & Polystyrene & 0.02 & 0.38 \\
Exterior wall_Brick & Brick & 0.10 & \\
& Polystyrene & 0.08 & 0.57 \\
Exterior wall_concrete & Brick & 0.10 & \\
& Concrete & 0.15 & 1.99 \\
Intermediate wall & Polystyrene & 0.05 & \\
& brick & 0.10 & 2.13 \\
Interior wall_Brick & Concrete & 0.05 & 2.99 \\
Interior wall_concrete & Hollow block & 0.17 & 2.68 \\
Low slab & Brick & 0.10 & 2.32 \\
Crawl space & Concrete & 0.15 & 2.22 \\
Windows & Concrete & 0.05 & \\
\hline
\end{tabular}

\subsection{Solar collectors}

The solar collector used in the study is a BIPVT collector (Type 650) (Duffie \& Beckman, 2016). It is a traditional thermal collector device integrating a PV layer, which produces simultaneously heat and electricity. The most important parameters for the evaluation of the BIPVT collectors are electrical and thermal efficiencies.

The PV electrical efficiency $\left(\eta_{\text {elc }}\right)$ is calculated using its nominal power at standard test conditions $\left(P_{\text {elc,stc }}\right)$ as follows:

$$
\eta_{e l c}=\frac{P_{e l, s t c}}{G \cdot A_{B I P V T}}
$$

$\eta_{\text {el }}$ can be also expressed as a function of the PV cell average temperature, $T_{\text {cell }}$ and the incident total solar radiation, $G$ :

$$
\begin{gathered}
\eta_{\text {elc }, \text { BIPVT }}=\eta_{0} \cdot\left[1+E f f_{T} \cdot\left(T_{\text {cell }}-T_{\text {ref }}\right)\right] . \\
{\left[+E f f_{G} \cdot\left(G-G_{r e f}\right)\right]}
\end{gathered}
$$

Where $T_{\text {ref }}$ and $G_{\text {ref }}$ are the reference temperature and the reference incident solar radiation, respectively, $\eta_{0}$ is the cell electric efficiency at the reference conditions.

The thermal efficiency of the BIPVT collector $\eta_{t h}$ is defined as the ratio of the useful heat production $Q_{B I P V T}$ to the available solar irradiation $\mathrm{G}$ :

$$
\eta_{t h}=\frac{Q_{B I P V T}}{G}
$$

The useful energy gain of BIPVT collector is calculated as:

$$
Q_{B I P V T}=\dot{m} . c p .\left(T_{f . o u t}-T_{f . i n}\right)
$$

Where $T_{f, \text { in }}$ and $T_{f, \text { out }}$ are the inlet and outlet fluid temperatures.

The fluid temperature at the outlet of BIPVT collector is calculated as:

$$
T_{\text {f.out }}=\left(T_{\text {f.in }}+\frac{\varepsilon}{k}\right) \exp \left(\frac{N_{\text {tubes }}}{\dot{m} \cdot c p} \cdot \frac{k}{\theta} \cdot L\right)-\frac{\varepsilon}{k}
$$

$N_{\text {tubes }}$ is the number of identical tubes carrying the fluid through the collector; $L$ is the tube length; $\varepsilon, \mathrm{k}$ and $\theta$ depend on the collector geometry, heat transfer coefficients, thermal resistances and temperatures of sky, ambient and back collector surface (Li et al., 2015).

\subsection{Adsorption chiller}

The adsorption chiller considered for the study is a single effect hot-water adsorption chiller. It is modeled using Type 909 and is equipped with open-circuit cooling tower, CT (Type 51) (Longo et al., 2017). The electricity used by fans and pumps are taking into consideration in the simulation of the whole system.

In order to reach the set point temperature, $T_{C H W, \text { set }}$, a certain amount of thermal energy should be removed from the entering chilled water (CHW). It can be calculated as follows:

$$
\dot{Q}_{C H W}=\dot{m}_{C H W} \cdot c p_{C H W} \cdot\left(T_{C H W, \text { in }}-T_{C H W, s e t}\right)
$$

Where $T_{C H W, \text { set }}$ is the set point temperature of the outlet chilled water stream.

The thermal energy removed from the hot water (HW) supplied to the chiller is given by the following equation. 


$$
\dot{Q}_{H W}=\frac{\dot{Q}_{\mathrm{CHW}}}{\operatorname{COP}_{A d C H}}
$$

The heat rejected to the cooling water stream $(\mathrm{CW})$ is given by:

$$
\dot{Q}_{C W}=\dot{Q}_{C H W}+\dot{Q}_{H W}+E_{A d C H}
$$

Where, $E_{\text {AdCH }}$ is the auxiliary power required by the adsorption chiller.

The coefficient of performance (COP) of the adsorption chiller is defined as:

$$
{ }_{C O P} P_{A d C H}=\frac{\dot{Q}_{C H W}}{E_{A d C H}+\dot{Q}_{H W}}
$$

\subsection{Heat pump}

The water-to-water heat pump is simulated by using type 669 from TRNSYS library. It is used in heating operation mode for supplying space heating. The heat pump COP is the ratio between the nominal capacity of the heat pump $\left(N C_{H P}\right)$ and its electrical energy consumption $\left(E_{H P}\right)$, as follows (Mitchell \& Braun, 1997):

$$
C O P_{H P}=\frac{N C_{H P}}{E_{H P}}
$$

In heating mode, the heat absorbed from the source liquid stream $\dot{Q}_{a b}$ is given by:

$$
\dot{Q}_{a b}=N C_{H P}-E_{H P}
$$

The outlet temperatures of the two water streams (source and load) are given by:

$$
\begin{aligned}
& T_{\text {source,out }}=T_{\text {source,in }}-\frac{\dot{Q}_{a b}}{\dot{\mathrm{m}}_{\text {source }} c p_{\text {source }}} \\
& T_{\text {load,out }}=T_{\text {load,in }}-\frac{N C_{H P}}{\dot{\mathrm{m}}_{\text {load }} c p_{\text {load }}}
\end{aligned}
$$

\subsection{Gas-fired auxiliary heater}

The gas-fired auxiliary heater, $A H$, is modeled using (Type 6) for supplying additional heating to the system. In our case, auxiliary heater is used to supply auxiliary thermal energy required for the chiller and DHW production.

The auxiliary heat transferred to fluid is given by the following equation:

$$
\dot{Q}_{A H}=\frac{\dot{\mathrm{m}} \cdot c p \cdot\left(T_{s e t}-T_{i n}\right)+U A \cdot\left(\bar{T}-T_{a}\right)}{\eta_{A H}}
$$

Where $\bar{T}=\frac{T_{\text {set }}+T_{\text {in }}}{2}$, and $T_{\text {set }}$ is the set point temperature of outlet fluid, $T_{a}$ is the ambient temperature and $\eta_{A H}$ is the auxiliary heater efficiency.

\section{Energy-economic model}

In order to study the feasibility of the solar system under investigation, an energy-economic model is proposed. The model includes the thermal and electrical solar fractions, the primary energy consumption, the primary energy saving achieved by the use of the solar system instead of the conventional one and the simple payback period.

\subsection{Thermal and electrical solar fractions}

The thermal solar fraction $\left(S F_{t h}\right)$ of the considered solar system is determined as the ratio between the thermal energy collected by the BIPVT field $\left(Q_{B I P V T}\right)$ and the heat delivered by auxiliary heater to drive the adsorption chiller $\left(Q_{A H, A d C H}\right)$ and DHW production $\left(Q_{A H, D H W}\right)$, as follows:

$$
S F_{t h}=1-\frac{Q_{P V T}}{Q_{A H, D H W}+Q_{A H, A C H}}
$$

While, the electrical solar fraction $S F_{\text {elc }}$ is the ratio between the electrical energy produced by the BIPVT field $\left(E_{B I P V T}\right)$ and the sum of electrical energy loads of the heat pump, adsorption chiller, pumps and lighting, as follows:

$$
S F_{\text {elc }}=1-\frac{E_{\text {BIPVT }}}{E_{H P}+E_{\text {AdCH }}+E_{P}+E_{\text {light }}}
$$

\subsection{Primary energy consumption (PEC)}

The primary energy consumption of the reference system is due to the electricity consumption of the electrical compression chiller $\left(E_{E C H}\right)$, circulating pump $\left(E_{p}\right)$ and lighting $\left(E_{\text {light }}\right)$ and the natural gas consumed by the gas-fired heaters for DHW preparation $\left(Q_{A H, D H W}\right)$ and space heating $\left(Q_{A H, S H}\right)$.

$$
P E C_{R S}=\frac{E_{E C H}+E_{p}+E_{\text {light }}}{\eta_{\text {elc }}}+\frac{Q_{A H, D H W}+Q_{A H, S H}}{\eta_{A H}}
$$

Where, $\eta_{A H}$ is the auxiliary gas-fired heater efficiency and $\eta_{\text {elc }}$ is the electricity efficiency at power plant.

The primary energy consumption of the solar system, in terms of conventional sources, is resulted in: i) the electricity consumption of circulating pumps $\left(E_{p}\right)$, adsorption chiller $\left(E_{A d C H}\right)$ and heat pump $\left(E_{H P}\right)$. ii) the natural gas consumption of the gas-fired auxiliary heater due to DHW production $\left(Q_{A H, D H W}\right)$ and the operation of the adsorption chiller $\left(Q_{A H, A d C H}\right)$. Noting that the electricity produced by BIPVT field $\left(E_{P V T}\right)$ is taken into consideration in the calculation of PEC as an energy gain.

$$
\begin{aligned}
& P E C_{P S}=\frac{E_{A d C H}+}{E_{H P}+E_{p}-E_{P V T}} \eta_{\text {elc }} \\
&+\frac{Q_{A H, D H W}+Q_{A H, A d C H}}{\eta_{A H}}
\end{aligned}
$$


Table 3

Solar system components costs (Canelli et al 2014; Vaishak \& Bhale, 2019)

\begin{tabular}{lcc}
\multicolumn{1}{c}{ System component } & Capacity & Cost function \\
BIPVT collectors & $100 \mathrm{~m}^{2}$ & $600 \times A_{B I P V T}$ \\
Water tank & $3 \mathrm{~m}^{3}$ & $495.9+808 \times V_{T K}$ \\
AdCH & $25 \mathrm{~kW}$ & $300 \times P_{A d C H}$ \\
Cooling tower & - & $0.005 \times \mathrm{p}_{\mathrm{CT}}^{2}+13.31 P_{C T}+885.5$ \\
Heat pump & $30 \mathrm{~kW}$ & $4.7108 \times \mathrm{NC}_{\mathrm{HP}}^{2}+139.69 \times N C_{H P}+3845.7$ \\
Auxiliary heater & $15 \mathrm{~kW}$ & $102 Q_{A H}$ \\
Circulation pump & - & $167 €$ \\
Controller & - & $170 €$ \\
\end{tabular}

\subsection{Primary energy saving (PES)}

The primary energy saving (PES) achieved by the use of solar system, instead of the reference one, is given by:

$$
P E S=P E C_{R S}-P E C_{P S}
$$

\subsection{Simple payback period (SPB)}

The economic feasibility of the studied solar system was investigated considering the Payback Period method (SPB):

$$
S P B=\frac{I C_{P S}-I C_{R S}}{O C_{R S}-O C_{P S}}
$$

Where: $I C_{R S}$ and $I C_{P S}$ are the investment capital costs of reference and solar systems, respectively, whereas $O C_{R S}$ and $O C_{P S}$ are the annual operating costs of the reference and solar system, respectively. The costs of solar system components are presented in Table 3.

The operating cost of the RS is calculated as follows:

$$
O C_{R S}=P E C_{e l c, R S} \times C_{e l c}+P E C_{N G, R S} \times C_{N G}
$$

The operating cost of the PS is calculated as follows:

$$
O C_{P S}=P E C_{e l c, P S} \times C_{e l c}+P E C_{N G, P S} \times C_{N G}
$$

Where, $C_{e l}$ and $C_{N G}$ represent the price of electricity (0.04 $€ / \mathrm{kWh})$ and natural gas $(0.004 € / \mathrm{kWh})$, respectively.

\section{Simulation results and discussions}

The performance of the proposed polygeneration system is investigated under Mediterranean climate (Algiers), Algeria. As previously indicated, the system will produce thermal and electrical energies for a typical multi-storey building. The heating and cooling energy demands of the reference building (without solar system) are estimated by TRNSYS software. The annual heating and cooling demands are $11.3 \mathrm{MWh} / \mathrm{y}$ and $15.4 \mathrm{MWh} / \mathrm{y}$, respectively. While, the DHW and electrical energy demands are 60 $\mathrm{MWh} / \mathrm{y}$ and $13.5 \mathrm{MWh} / \mathrm{y}$, respectively.

\subsection{System performance}

In this section, the thermal and electrical as well as economic performances of the proposed solar system are analyzed in terms of daily, monthly and yearly simulation results.

\subsubsection{Daily results}

The daily simulation results of the solar system are presented by selecting two representative winter and summer days. Figure 4 shows the system energy flows of the solar system during the selected winter day. It can be noticed that the heat and electricity generated by the BIPVT solar collectors are directly related to the potential of solar energy. The maximum energy productions $\left(Q_{B I P V T}=56 \mathrm{kWh}\right)$ and $\left.E_{B I P V T}=8 \mathrm{kWh}\right)$ are reached at 1:00 p.m., corresponding to the maximum solar energy (77 $\mathrm{kWh}$ ). The heat output from BIPVT field is entirely delivered to TK1 during the first part of the day (between 8:00 a.m. and 12:00 a.m.). In this period, the heat pump is turn on to keep TK3 temperature within the temperature range $\left(45^{\circ} \mathrm{C}-50^{\circ} \mathrm{C}\right)$. The thermal energy $Q_{T K 3}$ is transferred from TK3 to the building between 9:00 a.m. and 11:00 a.m. to keep its indoor air temperature at winter set-point temperature (up to $20^{\circ} \mathrm{C}$ ). In the remaining part of the day (between 12:00 a.m. and 5:00 p.m.), when TK3 is thermally loaded and the building energy demand is absent, the thermal energy is delivered to TK2 for DHW production. Auxiliary heater is used to adjust the temperature of DHW at $45^{\circ} \mathrm{C}$.

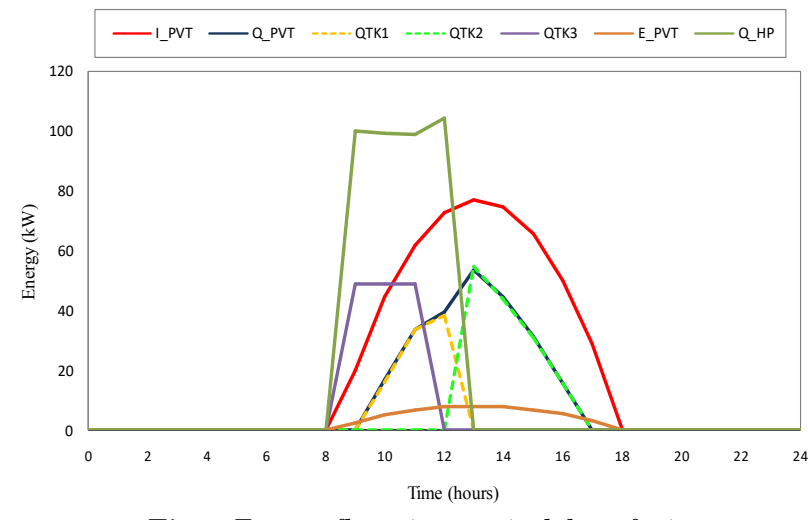

Fig 4. Energy flows in a typical day of winter 


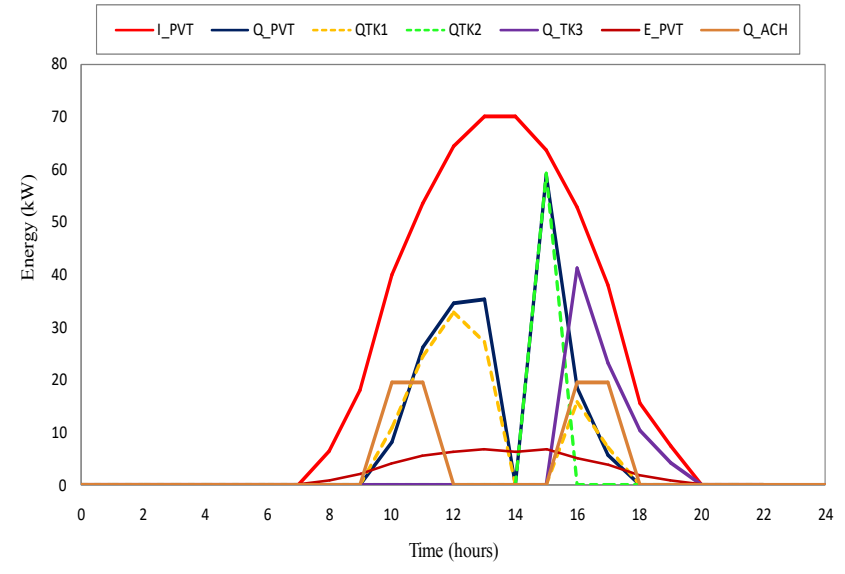

Fig 5. Energy flows in a typical day of summer

The daily results for the representative summer day are shown in Figure 5. As shown, a great part of thermal energy is delivered to TK1 for satisfying the high thermal energy required by the adsorption chiller, which will supply the energy demand for space cooling. Indeed, the later is turned on two times in the day, from 10:00 a.m. to 12:00 p.m. and from 4:00 p.m. to 6:00 p.m. to keep TK3 temperature within the range $\left(12^{\circ} \mathrm{C}-15^{\circ} \mathrm{C}\right)$.

In case of insufficient heat from TK1, auxiliary thermal energy is delivered by the gas-fired heater to complete the heat needed for the proper functioning of the adsorption chiller. Only a small part of thermal energy is transferred to TK2 between 2:00 p.m. and 4:00 p.m. to produce DHW. Therefore, hot water at $45^{\circ} \mathrm{C}$ for users is ensured by auxiliary heater. The energy demand for space cooling occurs between 4:00 p.m. and 8:00 p.m. and cold water is pumped directly from TK3 to the building to keep its indoor air temperature at summer set-point temperature (under $25^{\circ} \mathrm{C}$ ).

From daily results, it can be concluded that a significant part of electrical and thermal energy demands is supplied by BIPVT solar collectors; however, auxiliary energies from the grid and gas-fired heater are mandatory due to the solar energy fluctuations and intermittency.

\subsubsection{Monthly results}

The system performance is also investigated in term of monthly results to more clarify the energy behavior of the solar system during the different periods of the year. Figure 6 shows the monthly thermal energies produced by the solar collectors and the auxiliary heater, and the associated solar thermal fraction $\left(S F_{t h}\right)$. As mentioned above, the thermal energy $\left(Q_{B I P V T}\right)$ generated by BIPVT field is related to the availability of solar radiation. It is important in hot months and lower in cold months. For example: the maximum $Q_{B I P V T}$ is $4 \times 10^{3} \mathrm{kWh}$ in January and $6 \times 10^{3} \mathrm{kWh}$ in July. The same thing is happened for the heat delivered by auxiliary heater, which is higher in summer and lower in winter. Indeed, important solar fractions $\left(S F_{t h}\right)$, ranging between 0.66 and 0.75 , are noticed in winter due to the low thermal energy required for the operation of the heat pump, which is entirely supplied by solar energy. However, the lowest solar fractions are observed in summer (0.42-0.46).

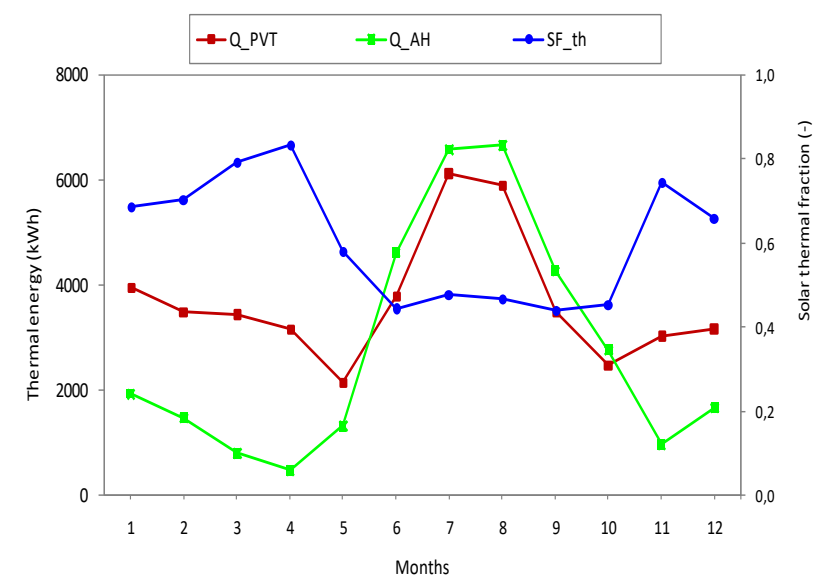

Fig 6. Monthly thermal energy flows of the solar system

This is due to the high thermal energy required by the adsorption chiller. In this period, the produced thermal energy is entirely used as a thermal source for the adsorption chiller and thus DHW demand is totally ensured by the auxiliary heater (ex. $6.66 \times 10^{3} \mathrm{kWh}$ in August).

The highest solar fraction is achieved in middle season $\left(S F_{t h}=0.83\right.$ in April) because of the low/or absent energy demand of the building and thus the produced thermal energy in this period is used only for DHW production.

Figure7 shows the monthly electrical energies produced by the BIPVT filed, used by the adsorption chiller and the heat pump, and the associated electrical solar fraction $\left(S F_{e l}\right)$. It can be noticed that the electrical energy output from the BIPVT field $\left(E_{B I P V T}\right)$ can cover a great part of electrical energy demand during hot months $\left(S F_{e l}=0.9\right.$ in July). This is mainly due to the high solar energy availability in this period, in addition to the low electrical energy used by the adsorption chiller. Moreover, the total electricity demand is supplied by BIPVT field in middle season $\left(S F_{e l}=1\right.$ in May, June and September). In this period, the produced electricity is used only for circulating pump and lighting, as the cooling energy demand of the building is very low or absent. The lowest electrical solar fractions are observed in cold months due to the high electrical energy used by the heat pump and scarce solar radiation. For example: in January, the electrical energy used by heat pump is $1890 \mathrm{kWh}$ with a $S F_{e l}$ of 0.39 .

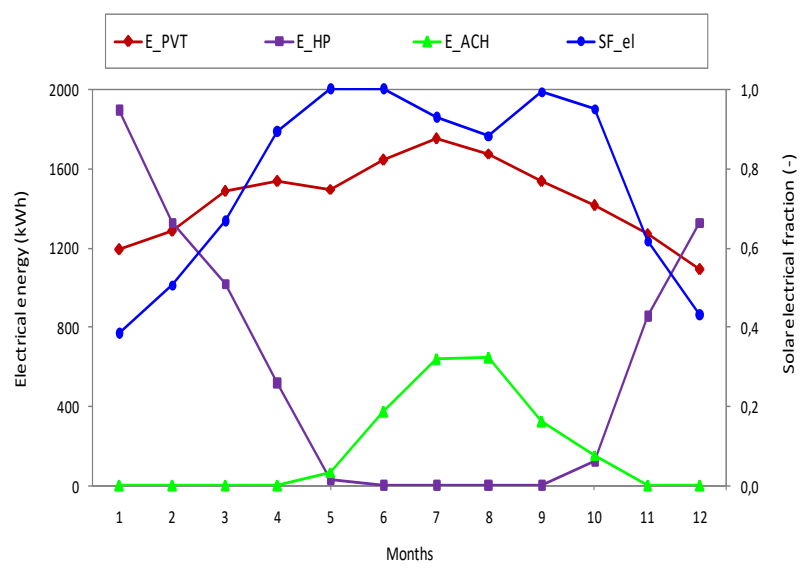

Fig 7. Monthly electrical energy flows of the solar system 


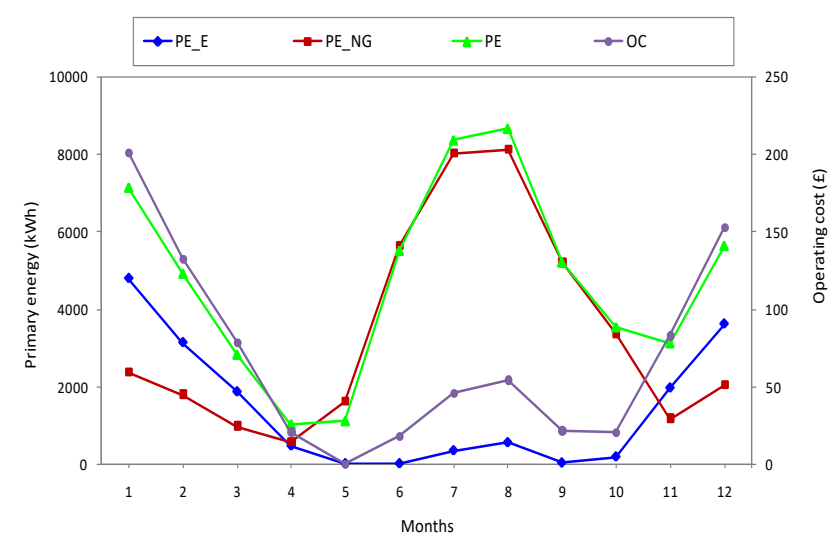

Fig 8. Monthly primary energy consumption and operating cost of the solar system

Figure 8 shows the monthly primary energy consumptions related to the natural gas and electricity of the solar system. It can be noticed that the primary energy consumption related to natural gas is higher in hot season and lower in cold season. For example: $8.4 \times 10^{3} \mathrm{kWh}$ in August and $2.52 \times 10^{3} \mathrm{kWh}$ in January. This is can be explained by the high amount of natural gas consumed by the auxiliary heater to meet the thermal energy required for the operation of adsorption chiller in summer. However, the opposite is occurred for the primary energy consumption related to electrical energy, which is important in winter (ex. $4.9 \times 10^{3} \mathrm{kWh}$ ). This is due to the important amount of electrical energy consumed by the heat pump in winter. It is shown also that the associated operating cost of the solar system in cold months is higher than that in hot months. This is due to the relatively higher price of electricity $(0.04 € / \mathrm{kWh})$ in comparison to that of natural gas $(0.004 € / \mathrm{kWh})$.

From the investigation of the solar system in term of monthly results, it was found that the later can supply a great part of the energy demands of the building efficiently. This occurs thanks to the simultaneous production of heat and electricity by BIPVT solar collectors, in addition to the use of the two efficient heatdriven devices ( $\mathrm{HP}$ and $\mathrm{AdCH}$ ).

\subsubsection{Yearly results}

Table 4 summarizes the year-round simulation results of the solar system for the weather condition of Algiers. In such Table, electrical and thermal energy productions, primary energy consumption and primary energy saving achieved by the system are also presented.

The contribution of the energy produced by the BIPVT solar collectors is very important. Indeed, the yearly produced thermal energy $\left(Q_{B I P V T}\right)$ is $44.1 \times 10^{3} \mathrm{kWh} /$ year. It covers $56 \%$ (solar thermal fraction) of the total thermal energy demand (the operation of the HP, AdCH and DWH production). A great part of this thermal energy (34.1 $\times 10^{3}$ $\mathrm{kWh} /$ year) is supplied to the heat pump and adsorption chiller and only $7.12 \times 10^{3} \mathrm{kWh} /$ year is used for DHW production. Meanwhile, the electrical energy produced by solar collectors $\left(E_{B I P V T}\right)$ is $17.3 \times 10^{3} \mathrm{kWh} /$ year; it represents $72 \%$ (solar electrical fraction) of the total electrical energy demand.

The BIPVT electrical $\left(\eta_{\mathrm{el}}\right)$ and thermal ( $\left.\eta_{\mathrm{th}}\right)$ efficiencies, calculated with respect to the total absorbed solar radiation, are over $28 \%$ and $11 \%$, respectively. These efficiencies are relatively low, because the average temperature in the Mediterranean climate is low, and thus the thermal losses of the BIPVT collector are significant.

The yearly COP of the adsorption chiller is 0.51 , which is near to the nominal one (0.53). This occurs because the hot side of the adsorption chiller is always maintained between $60^{\circ} \mathrm{C}$ and $65^{\circ} \mathrm{C}$ by the gas-fired auxiliary heater. Moreover, the yearly mean COP of the water-to-water heat pump is 3.8 since solar energy is not always able to satisfy the operating temperature of the heat pump.

The annual primary energy consumption of the solar system $\left(5.70 \times 10^{4} \mathrm{kWh} / \mathrm{y}\right)$ is lower compared to the primary energy consumed by the reference system $\left(9.42 \times 10^{4}\right.$ $\mathrm{kWh} / \mathrm{y}$ ), leading to a lower annual operating cost of $819 €$, with an operating cost saving of $1791 € /$ year. Regarding the primary energy saving, more than $37 \times 10^{3} \mathrm{kWh}$ of energy is annually saved, which represents a reduction of $39 \%$ of the electricity and natural gas used by the reference system. However, the initial cost of the system under investigation is very high $\left(116287 €\right.$, about $\left.1100 € / \mathrm{m}^{2}\right)$, in comparison to the cost of the reference system $(17000 €)$. It is mainly due to the BIPVT filed which accounts for $57 \%$ of the total system cost. Therefore, the calculated simple payback period is 55.40 years. The later is high than the considered life span of the polygeneration system (20 years).

It can be concluded that, although the significant energy savings achieved by the solar system, its economical achievability is not possible because of the high initial cost of solar energy components and lower unitary prices of gas and electricity in Algeria.

\subsection{Sensitivity analysis}

In this study, in order to determine the optimal sizes of the solar system components and to find the best solutions that make the solar system under investigation economically profitable, a sensitivity analysis is conducted. Thus, the effects of various designs and economical parameters such as BIPVT field area, tank volume, system cost, fossil fuel prices and climate conditions on the energetic and economic performances of the system, are investigated.

Table 4.

Annual thermal, electrical and economic results

\begin{tabular}{ccc}
\hline Parameter & Value & Unit \\
\hline$I_{B I P V T}$ & $1.56 \times 10^{5}$ & $\mathrm{KWh} / \mathrm{y}$ \\
$E_{B I P V T}$ & $1.73 \times 10^{4}$ & $\mathrm{KWh} / \mathrm{y}$ \\
$Q_{B I P V T}$ & $4.41 \times 10^{4}$ & $\mathrm{KWh} / \mathrm{y}$ \\
$Q_{A H, D H W}$ & $1.57 \times 10^{4}$ & $\mathrm{KWh} / \mathrm{y}$ \\
$E_{H P}$ & $7.16 \times 10^{3}$ & $\mathrm{KWh} / \mathrm{y}$ \\
$Q_{A H, A d C H}$ & $1.76 \times 10^{4}$ & $\mathrm{KWh} / \mathrm{y}$ \\
$E_{A d C H}$ & $2.19 \times 10^{3}$ & $\mathrm{KWh} / \mathrm{y}$ \\
$S F_{\text {elc }}$ & 0.72 & - \\
$S F_{t h}$ & 0.56 & - \\
$\eta_{t h}$ & 0.28 & - \\
$\eta_{\text {elc }}$ & 0.11 & - \\
$C O P_{H P}$ & 3.8 & - \\
$C O P_{A d C H}$ & 0.51 & - \\
$P E C_{R S}$ & $9.42 \times 10^{4}$ & $\mathrm{KWh} / \mathrm{y}$ \\
$P E C_{P S}$ & $5.70 \times 10^{4}$ & $\mathrm{KWh} / \mathrm{y}$ \\
$P E S$ & $3.71 \times 10^{3}$ & $\mathrm{KWh} / \mathrm{y}$ \\
$P E S \mathrm{r}$ & 0.39 & - \\
$I C_{R S}$ & 17004 & $€$ \\
$O C_{R S}$ & 2610 & $€ / \mathrm{year}$ \\
$I C_{P S}$ & $1.16 \times 10^{5}$ & $€$ \\
$O C_{P S}$ & 819 & $€ / \mathrm{year}$ \\
$O C S$ & 1791 & $€ / \mathrm{year}$ \\
$S P B$ & 55.40 & Years \\
\hline
\end{tabular}




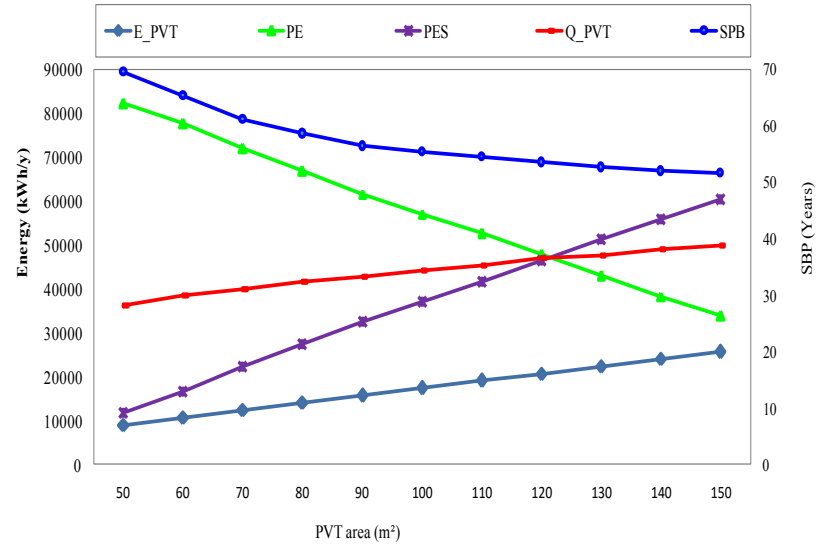

Fig 9. Variation of the energy and economic parameters in function of PVT area

\subsubsection{Effect of BIPVT area}

Figure 9 shows the effect of BIPVT field area on the annual system performance. Solar collector areas, from 50 $\mathrm{m}^{2}$ to $150 \mathrm{~m}^{2}$, are considered. However, a fixed storage tank volume of $30 \mathrm{~L} / \mathrm{m}^{2}$ and a fixed flow rate of $50 \mathrm{~L} / \mathrm{m}^{2}$ are considered. It can be noticed that the produced electrical and thermal energies are proportional to the BIPVT area. They increase as the BIPVT area increases. At a BIPVT area of $150 \mathrm{~m}^{2}$, the produced thermal and electrical energies reach $50 \times 10^{3} \mathrm{kWh} / \mathrm{y}$ and $26 \times 10^{3} \mathrm{kWh} / \mathrm{y}$, respectively. It is also shown that the increase of the BIPVT area reduces the primary energy consumption and increases consequently the primary energy saving. For example: At a BIPVT area of $150 \mathrm{~m}^{2}$, The PEC decreases to $33 \times 10^{3} \mathrm{kWh} / \mathrm{y}$ and the PES increases to $60 \times 10^{3} \mathrm{kWh} / \mathrm{y}$. The economic results show that the SPB decreases sharply (from 70 to 61 years) for BIPVT areas between 50 and 70 $\mathrm{m}^{2}$. Between 70 and $90 \mathrm{~m}^{2}$, the decrease in SPB is gradually. Beyond $90 \mathrm{~m}^{2}$, it becomes less important. It can be concluded that the system performance is influenced highly by the BIPVT area. An optimal size of $70 \mathrm{~m}^{2}$ could be considered.

\subsubsection{Effect of the tank volume}

The influence of the tank volume (from $10 \mathrm{~L} / \mathrm{m}^{2}$ to 100 $\mathrm{L} / \mathrm{m}^{2}$ ) on the performance of the system is shown in Figure 10. Fixed BIPVT area and flow rate of $100 \mathrm{~m}^{2}$ and $50 \mathrm{~L} / \mathrm{m}^{2}$, respectively, are considered.

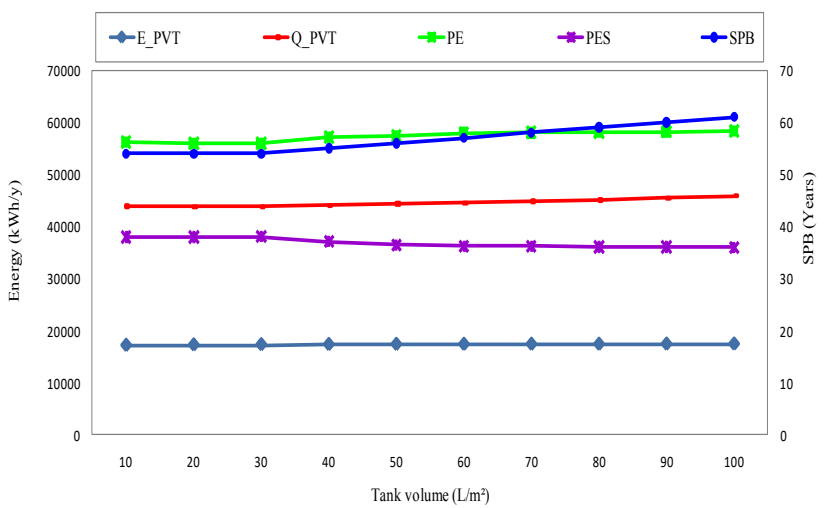

Fig 10. Variation of energy and economic parameters in function of tank volume
The results show that the increase of tank volume affects scarcely the system performance. For tank volumes ranging between $10 \mathrm{~L} / \mathrm{m}^{2}$ and $100 \mathrm{~L} / \mathrm{m}^{2}$, the thermal and electrical energy productions increase slightly $(0.04 \%$ and $0.017 \%$, respectively). A small decrease in PEC is reported between 10 and $30 \mathrm{~L} / \mathrm{m}^{2}$, which increases the PES and reduces slightly the SPB of the system. As a result, a storage volume tank of $30 \mathrm{~L} / \mathrm{m}^{2}\left(3 \mathrm{~m}^{3}\right)$ can be considered as an optimal size.

\subsubsection{Effect of system cost}

In Algeria, as the cost of fossil fuel energy is strongly incentivized by the state, the costs of electricity $(0.04$ $€ / \mathrm{kWh})$ and natural gas $(0.004 € / \mathrm{kWh})$ are among the cheapest in the world. Meanwhile, no supports have been provided for the solar energy components which are still not mature. In this circumstance, the economic profitability of renewable energy systems is difficult to be achieved.

Figure 11 shows the impact of the solar system cost on its economic performance. System costs from 200 to 1400 $€ / \mathrm{m}^{2}$ are investigated. It is clearly shown that for a system cost of approximately $1200 € / \mathrm{m}^{2}$ (without investment subsidy), the SPB is more than 65 years, which is higher than the considered life cycle of the system (20 years). However, the system becomes economically profitable ( $\mathrm{SPB}=13$ vyears) when the capital cost is lower than 400 $\left(€ / \mathrm{m}^{2}\right)$, with a corresponding capital investment subsidy is about $66 \%$. The SPB of the solar system is strongly reduced if the capital investment subsidy reaches $80 \%$, with a system cost lower than $200\left(€ / \mathrm{m}^{2}\right)$. Thus, the system cost has a direct impact on its economic viability.

\subsubsection{Effect of electricity cost}

The economic performance of the solar system is studied for various electricity costs, from 0.04 to $0.12 € / \mathrm{kWh}$. Figure 12 shows the effect of the electricity cost on the SPB of the solar system. It can be noticed that the SPB is strongly affected by the unitary cost of the electrical energy. Noting that the current cost of the electrical energy is $0.04 € / \mathrm{kWh}$, while the real cost (without incentive) is $0.12 € / \mathrm{kWh}$. Thus, more than $66 \%$ of the electricity cost is subdivided by Algerian government.

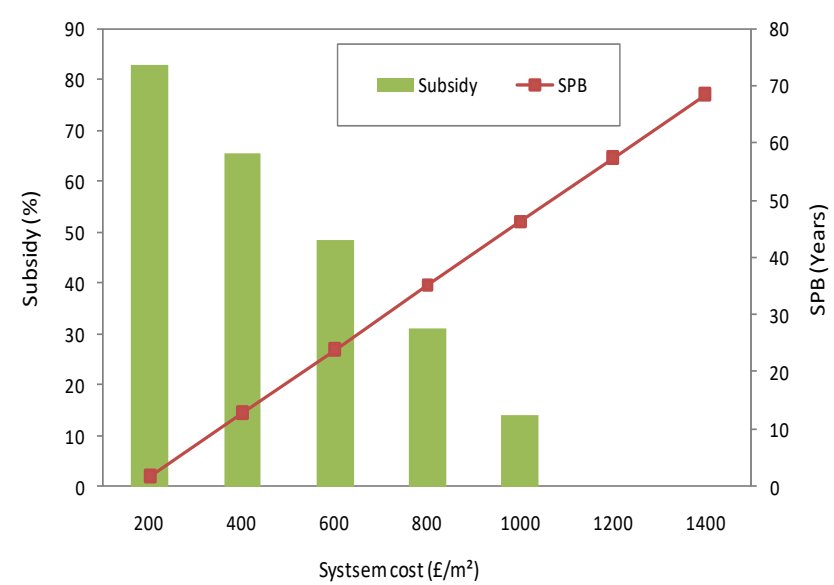

Fig 11. SPB and capital investment subsidy as a function of system cost 


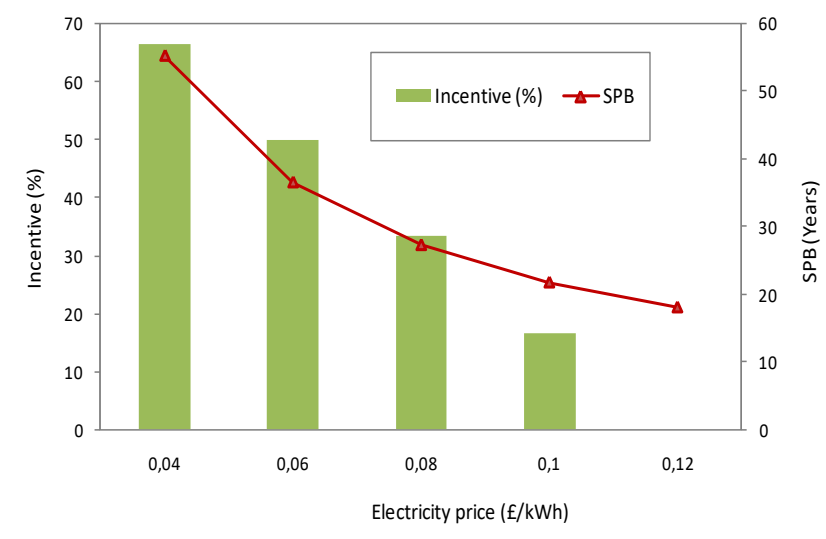

Fig 12. SPB as a function of electricity price.

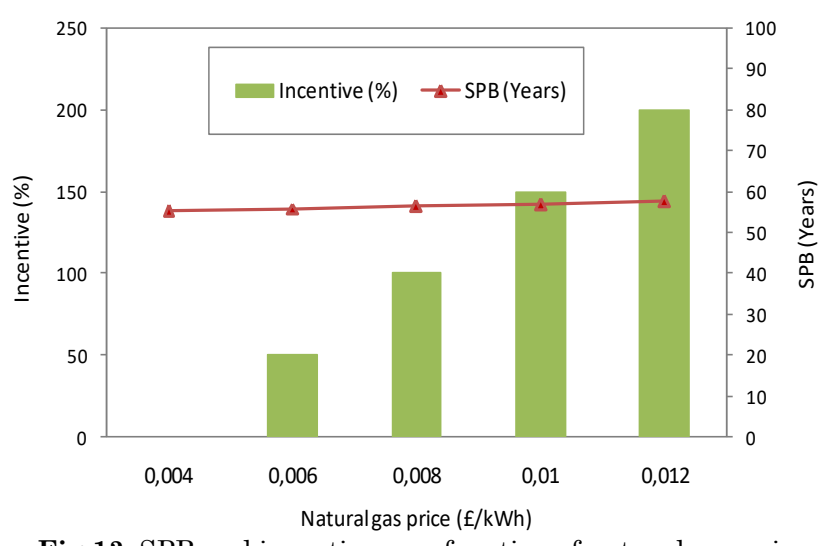

Fig 13. SPB and incentive as a function of natural gas price

As mentioned above, for the current electricity cost, the SPB of the solar system is higher than 20 years. However, when the real cost of electricity is considered (no incentive for electricity), the SPB decreases to 17.7 years. Consequently, for the feasibility of the system, the subsidy of electricity cost must be strongly reduced or lifted.

\subsubsection{Effect of natural gas cost}

In Figure13, is shown the variation of SPB as a function of natural gas price. Unitary prices of natural gas, ranging from 0.004 to $0.012 € / \mathrm{kWh}$, are considered. As shown, the increase of the natural gas price has not an important impact on the SPB due to its very low cost, compared to the unitary price of electricity. A small increase in SPB of 3 years is registered when the natural gas is increased from 0.004 to $0.012 € / \mathrm{kWh}$.

\subsubsection{Effect of climate conditions}

The load profiles of a building are affected strongly by the in-situ climate conditions. Therefore, more attention should be paid to the climate zone when designing solar systems for buildings. In Algeria, there are different climate zones. They are classified into three great climate zones, warm and humid zone (Mediterranean climate), hot summer and cold winter zone (highland region) and hot and dry zone (desert climate) (Toudert \& Weidhaus, 2017, Missoum et al., 2016). In other hand, Algeria enjoys of an important solar potential. The sunshine duration is about 7.3 hours in the North, 8.3 hours in the highlands and more than 10 hours in Southern regions (Abada \& Bouharkat, 2018).

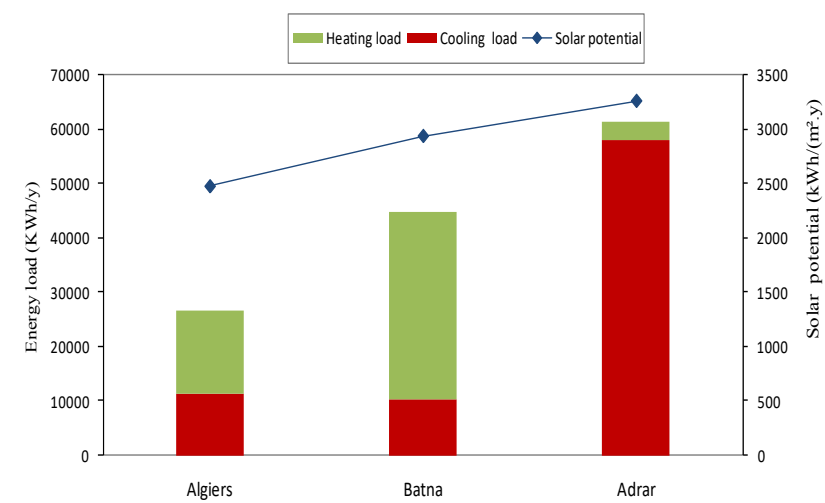

Fig 14. Annual energy loads of the reference building and solar potential in the three considered cities.

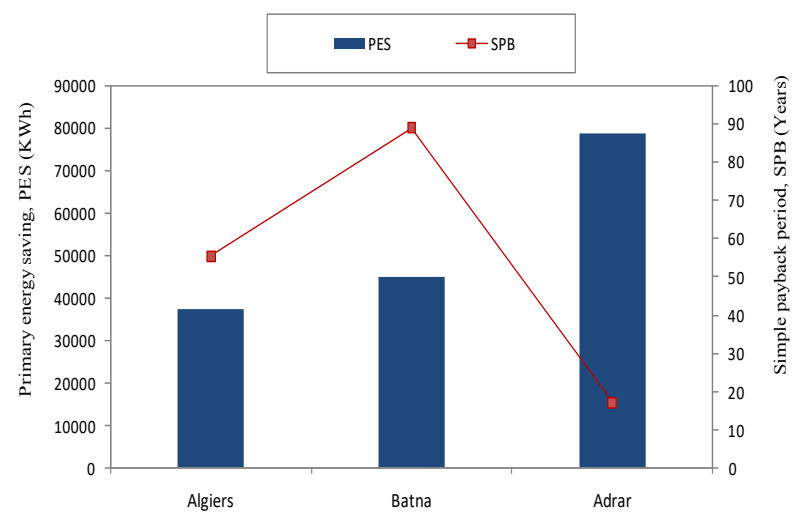

Fig 15. PES and SPB achieved in the three considered cities

In order to study the effect of the local climate conditions on the performance of the system under investigation, three cities are considered, Algiers, Batna and Adrar, which are corresponding to the above mentioned three climate zones. In Figure 14, is shown the annual energy loads of the reference building and the solar potential in the three considered cities.

It can be noticed that Batna weather zone can be considered as heating-dominated. Indeed, the energy required for space heating is $34.4 \times 10^{3} \mathrm{kWh} / \mathrm{y}$, which is higher than that needed for space cooling $\left(10.4 \times 10^{3}\right.$ $\mathrm{kWh} / \mathrm{y}$ ). The contrary is occurred in hot zones (Adrar), where energy needed for space cooling is very higher than the energy demand for space heating. The city of Algiers shows similar energy required for cooling (11.3 MWh/y) and heating $(15.4 \mathrm{MWh} / \mathrm{y})$ because of the pleasant Mediterranean climate conditions.

Figure 15 shows the annual PES and the SPB for the three cities. It can be noticed that the PES is affected strongly, in one hand, by the solar energy potential of the zone and, in other hand, by the cooling load. As space cooling is provided by electrical chiller and the conversion factor of electricity (2.5) is higher than that of natural gas (1.22), the largest PES is achieved in Adrar $\left(78.7 \times 10^{3} \mathrm{kWh}\right)$ due to the high energy required for space cooling. Further, although the high energy demand for space heating in Batna, the cities of Algiers and Batna present almost similar PES (37.1 $\times 10^{3}$ and $44.8 \times 10^{3} \mathrm{kWh}$, respectively). Moreover, the SPB (88.9 years) for Batna is the worst because of the lower cost of natural gas. The best SPB is achieved in desert climate of Adrar (17.9 years), followed by Algiers (55.4 years). In other words, the best viability of the solar system is obtained in hot climate, where the 
building cooling demand is very high and solar energy is abundant.

Finally, the sensitivity analysis shows that the system performance is greatly affected by the solar field area, system cost, unitary cost of electricity and the climate conditions of the zone where the system is installed.

\section{Conclusion}

A complete analysis of the performance of a solar polygeneration system is carried out in this work. The solar system includes of an adsorption chiller and a waterto-water heat pump, both driven by BIPVT solar collectors. The system supplies space heating and cooling and produces DHW and electricity for a typical high-energy performance multi-family building located in Algeria. The heat output from the BIPVT collectors is delivered to the heat pump in heating season and to adsorption chiller in cooling season and the excess is used to the DHW preparation. The solar system coupled to the building as well as the energy demand of the reference building have been dynamically simulated using TRNSYS software. The results conducted in this paper are shown below.

- The annual thermal and electrical energies produced by the BIPVT field can cover, respectively, more than $56 \%$ and $72 \%$ of the heat and electricity demands. Meanwhile, the thermal and electrical efficiencies of solar collector's field are 0.28 and 0.11 , respectively.

- In winter, space heating is entirely supplied by the heat pump, while auxiliary thermal energy is mandatory for the operation of the adsorption chiller in summer and DHW production all the year. As a result, the primary energy consumption related to the gas natural is higher in summer $\left(1.76 \times 10^{4} \mathrm{kWh} / \mathrm{y}\right)$. The opposite is occurred for the primary energy consumption related to electricity, where the operation of the heat pump consumes more electrical energy $\left(7.16 \times 10^{3} \mathrm{kWh} / \mathrm{y}\right)$ in winter, compared to that used in summer by the adsorption chiller $\left(2.19 \times 10^{3}\right.$ $\mathrm{kWh} / \mathrm{y})$.

- The mean yearly coefficient of performance of the heat pump and the adsorption chiller are, 3.8 and 0.51 , respectively.

- The primary energy saving achieved by the solar system is $37.10 \mathrm{MWh} / \mathrm{y}$, which represents a reduction of $39 \%$, with respect to the primary energy used by the reference system.

- Although the significant energy saving, the solar system is not economically profitable due to high investment capital cost of the solar system and low cost of fossil fuel in Algeria. Indeed, the obtained simple pay-back period is 55.40 years, which is lower than the life span of the solar system, considered to be 20 years.

- The system performance is strongly affected by the area of BIPVT collectors, in particular between 50 and $70 \mathrm{~m}^{2}$. However, it is scarcely sensible to the storage volume tank. Optimal sizes of $70 \mathrm{~m}^{2}$ and $3 \mathrm{~m}^{3}$ could be considered, respectively, for the BIPVT area and the storage tank volume.

- The system cost and unitary price of electricity have direct effects on the system performance. Whereas, the system performance is slightly affected by the variation of the unitary price of natural gas. The system is economically promising if the system cost is

lower than $400 € / \mathrm{m}^{2}$ and the electricity cost is more $0.12 € / \mathrm{kWh}$. Therefore, an investment subsidy of $60 \%$ should be considered, with the lifting of the incentive (67\%) provided by the government for the electricity cost.

- The system performance is the best in hot climate zone, where solar radiation is abundant and building cooling energy requirement is important. Indeed, the highest PES is achieved in hot climate of Adrar, 78.7 MWh/year, with a lower SPB of 17.10 years. Meanwhile, the system performance is the worst in cold climate of Batna, with a PES and SPB of 37.10 MWh/year and 88.90 years, respectively.

\section{Nomenclature}

\begin{tabular}{|c|c|}
\hline A & area, $\mathrm{m}^{2}$ \\
\hline $\mathrm{cp}$ & specific heat, J.kg-1. K-1 \\
\hline $\mathrm{C}$ & cost, $€$ \\
\hline $\mathrm{COP}$ & coefficient of performance, - \\
\hline $\mathrm{E}$ & electric power, kW \\
\hline EffT & temperature efficiency modifier,${ }^{\circ} \mathrm{C}^{-1}$ \\
\hline EffG & radiation efficiency modifier, $\mathrm{m}^{2} . \mathrm{W}^{-1}$ \\
\hline G & solar irradiance, $\mathrm{kW} \cdot \mathrm{m}^{-2}$ \\
\hline IC & investment cost, $€$ \\
\hline$\dot{\mathrm{m}}$ & mass flow rate, kg.h-1 \\
\hline $\mathrm{OC}$ & operating cost, $€$ \\
\hline OCS & operating cost saving, $€$ \\
\hline $\mathrm{P}$ & Nominal power, $\mathrm{kW}$ \\
\hline PEC & primary energy consumption, $\mathrm{kWh}$ \\
\hline PES & primary energy saving, $\mathrm{kWh}$ \\
\hline Q & thermal power, $\mathrm{kW}$ \\
\hline SF & solar fraction, - \\
\hline SBP & simple pay-back period, years \\
\hline $\mathrm{T}$ & temperature,${ }^{\circ} \mathrm{C}$ \\
\hline
\end{tabular}

\section{Greek} symbols

$\eta$

Subscripts

$\begin{array}{ll}\text { AH } & \text { Auxiliary heater } \\ \text { AdCH } & \text { Adsorption chiller } \\ \text { CHW } & \text { Child water } \\ \text { CT } & \text { Cooling tower } \\ \text { CW } & \text { Cold water } \\ \text { DHW } & \text { Domestic hot water } \\ \text { ECH } & \text { Electric chiller } \\ \text { elc } & \text { Electric } \\ \text { f } & \text { fluid } \\ \text { NG } & \text { Natural Gas } \\ \text { GH } & \text { Gas-fired heater } \\ \text { HP } & \text { Heat pump } \\ \text { HW } & \text { Hot water } \\ \text { in } & \text { Inlet } \\ \text { out } & \text { Outlet } \\ \text { p } & \text { Pump } \\ \text { PS } & \text { Polygeneration system } \\ \text { PV } & \text { photovoltaic } \\ \text { ref } & \text { Reference } \\ \text { RS } & \text { Reference system } \\ \text { SH } & \text { Space heating } \\ \text { set } & \text { Set-point } \\ \text { th } & \text { thermal } \\ \text { tot } & \text { total } \\ \text { TK } & \text { tank }\end{array}$




\section{Acknowledgements}

The authors would like to thank the General Direction of Scientific Research and Technological Development (DGRSDT) of Algeria for supporting this research.

\section{References}

Abada, Z. \& Bouharkat, M. (2018). Study of management strategy of energy resources in Algeria. Energy Reports, 4, 1-7; doi:10.1016/j.egyr.2017.09.004

Agrawal, B., Tiwari, G.N., 2010. Life cycle cost assessment of building integrated photovoltaic thermal (BIPVT) systems. Energy and Buildings. 42, 1472-1481; doi:10.1016/j.enbuild.2010.03.017

Alobaida, M., Hughes, B., Calautit, J.K., O'Connora, D., \& Heyes, A. (2017). A review of solar driven absorption cooling with photovoltaic thermal systems. Renewable and Sustainable EnergyReviews,76,728-742; doi:10.1016/j.rser.2017.03.081

Awani, S., Chargui, R., Kooli, S., Farhat, A., \& Guizani, A. (2015). Performance of the coupling of the flat plate collector and a heat pump system associated with a vertical heat exchanger for heating of the two types of greenhouses system. Energy Conversion and Management, 103,266-275; doi:10.1016/j.enconman.2015.06.032

Bahria, S., Amirat, M., Hamidat, A., El-Ganaoui, M., \& Slimani, M. El-A. (2016). Parametric study of solar heating and cooling systems in different climates of Algeria: A comparison between conventional and high-energy-performance buildings.Energy, 113,521535; doi:10.1016/j.energy.2016.07.02

Brahim, T., \& Jemni, A. (2017). Economical assessment and applications of photovoltaic/thermal hybrid solar technology: A review. SolarEnergy, 153, 540-561; doi:10.1016/j.solener.2017.05.081.

Buker, M.S., Mempouo, B., \& Riffat, S.B. (2005). Experimental investigation of a building integrated photovoltaic/thermal roof collector combined with a liquid desiccant enhanced indirect evaporative cooling system. Energy Conversion and Management, 101, 239-54.

Buonomano, A., Calise, F., Palombo, A., \& Vicidomini, M. (2016). BIPVT systems for residential applications: An energy and economic analysis for European climates. Applied Energy, 184, 1411-1431; doi:10.1016/j.apenergy.2016.02.145.

Buonomano, A., Calise, F., \& Palombo, A. (2018). Solar heating and cooling systems by absorption and adsorption chillers driven by stationary and concentrating photovoltaic/thermal solar collectors: Modelling and simulation. Renewable and Sustainable Energy Reviews,82,1874-1908; doi:10.1016/j.rser.2017.10.059

Buonomano, A., Calise, F., Palombo, A., \&Vicidomini, M. (2019). Transient analysis, exergy and thermo-economic modelling offaçade integrated photovoltaic/thermal solar collectors. Renewable Energy, 137, 109-126; doi:10.1016/j.renene.2017.11.060

Buonomano, A., Calise, F., Palombo, A., \& Vicidomini, M. (2017). Adsorption chiller operation by recovering low-temperature heat from building integrated photovoltaic thermal collectors: modelling and simulation. Energy Convers Manage, 149, 1019-36; doi:10.1016/j.enconman.2017.05.005

Calise, F., d'Accadia, M.D., \& Vanola, L. (2012). Design and dynamic simulation of a novel solar trigeneration system based on hybrid photovoltaic/thermal collectors (PVT). Energy Conversion and Management, 60, 214-225; doi:10.1016/j.enconman.2012.01.025

Calise, F., d'Accadia, M.D., Figaj, R.D., \& Vanoli, L. (2016). A novel solar-assisted heat pump driven by photovoltaic/thermal collectors :Dynamic simulation and thermos economic optimization.Energy, 95,346-366; doi:10.1016/j.energy.2015.11.071

Calise, F., Vastogirardi, G. de N. di., d'Accadia, M. D., \&Vicidomini, M. (2018). Simulation of polygenerationsystems. Energy, 163, 290-337; doi:10.1016/j.energy.2018.08.052.
Calise, F., Figaj, R.D., \& Vanoli, L. (2017). A novel polygeneration system integrating photovoltaic/thermal collectors, solar assisted heat pump, adsorption chiller and electrical energy storage: Dynamic and energy economic analysis. Energy Conversion and Management,149,798814;doi:10.1016/j.enconman.2017.03.027

Calise, F., Cappiello, F.L., d'Accadia, M.D., \& Vicidomini, M., (2020).Dynamic simulation, energy and economic comparison between BIPV and BIPVT collectors coupled with microwindturbines.,Energy.19,116439;doi:10.1016/j.energy.2019.11 6439

Canelli, E., Entchev, M., Sasso, L., Yang, M., \& Ghorab, (2014). Dynamic simulations of hybrid energy systems in load sharing application. Applied Thermal Engineering, S13594311(14)01190-9; doi:10.1016/j.applthermaleng.2014.12.061

Costa, A., Marcus, M.K., Torrens, J.I., \& Corry, E., (2013).Building operation and energy performance: Monitoring, analysis and optimisation toolkit. Applied Energy, 101, 310-316; doi:10.1016/j.apenergy.2011.10.037.

Debbarmaa, M., Sudhakar, K., \& Baredar, P. (2017). Thermal modeling, exergy analysis, performance of BIPV and BIPVT: A review, Renewable and Sustainable Energy Reviews, 73, 1276-1288; doi:10.1016/j.rser.2017.02.035.

Duffie, J.A., \& Beckman, W.A. (2013). Solar Engineering of Thermal Processes. Wiley.

Fraga, C., Hollmuller, P., Mermoud, F., \& Lachal, B., (2017). Solar assisted heat pump system for multifamily buildings: Towards a seasonal performance factor of 5? Numerical sensitivity analysis based on a monitored case study. Solar Energy, 146, 543-564doi:10.1016/j.solener.2017.02.008

Guo, J., Lin, S., Bilbao, J.I., White, S.D., \& Sproul, A.B. (2017). A review of photovoltaic thermal (PV/T) heat utilisation with low temperature desiccant cooling anddehumidification.Renewable and Sustainable. Energy Reviews, 67,1-14;doi:10.1016/j.rser.2016.08.056

Kasaeian, A., Bellos, E., Shamaeizadeh, A., \& Tzivanidis, C., (2020).Solar-driven polygeneration systems: Recent progress andoutlook. Applied Energy, 264, 114764; doi.org/10.1016/j.apenergy.2020.114764.

Lamnatou, C, Mondol, J.D., Chemisana, D., \& Maurer, C., (2015). Modelling and simulation of Building-Integrated solar thermal systems: Behaviour of the system. Renewable and Sustainable Energy Reviews 45, 3651;doi:10.1016/j.rser.2015.01.024

Li, S., Joe, J., Hu, J., \& Karava, P. (2015). System identification and model-predictive control of office buildings with integrated photovoltaic-thermal collectors, radiant floorheating and active thermal storage. Solar Energy, 113, 139-157; doi:10.1016/j.solener.2014.11.024

Longo, S., Palomba, V., Beccali, M., Cellura, M., \& Vasta, S., (2017). Energy balance and life cycle assessment of small size residential solar heating and cooling systems equipped with adsorption chillers. Solar Energy, 158, 543-558; doi:10.1016/j.solener.2017.10.009

TRNSYS, A Transient System Simulation Program, (2006)Version 16, Mathematical Reference Volume 5, Solar Energy Laboratory, University of Wisconsin-Madison, Madison, WI.

MEM, Ministry of energy and Mining. Final energy consumption of Algeria, (2019). http://www.aprue.org.dz/documents/Consommation $\% 20 \% \mathrm{C} 3$ \%A9nerg\%C3\%A9tique\%20finale.pdf

Missoum, M., Hamidat, A., Loukarfi, L., \& Abdeladim, K., (2016). Impact of a grid-connected PV system application in a bioclimatic house toward the zero energy status in the north of Algeria. Energy and Buildings 128, 370-383; doi:10.1016/j.enbuild.2014.09.045

Mitchell, J.W., \& Braun, J.E. (1997). Design analysis, and control of space conditioning equipment and systems. Madison: Solar Energy Laboratory, University of Wisconsin.

Papoutsis, E.G., Koronaki, I.P., \& Papaefthimiou, V.D. (2017).Numerical simulation and parametric study of different types of solar cooling systems under Mediterranean 
climatic conditions. Energy and Buildings, 138,601611;doi:10.1016/j.enbuild.2016.12.094.

Plytaria, M.T., Tzivanidis, C., Bellos, E., \& Antonopoulos, K.A.(2018). Energetic investigation of solar assisted heat pump underfloor heating systems with and without phase change materials. Energy Conversion and Management. 173, 626-639; doi:10.1016/j.enconman.2018.08.010

Ramos, A., Chatzopoulou, M.A., Guarracino, L., Freeman, J.,\&Markides, C.N. (2017). Hybrid photovoltaicthermalsolarsystems for combined heating, cooling and power provision in the urban environment. Energy Conversion and Management, 150 , doi:10.1016/j.enconman.2017.03.024

Sancho, A. del A. (2014). Solar Trigeneration: A Transitory Simulation of HVAC Systems Using Different Typologies of Hybrid Panels. Journal of Sustainable Development of Energy,
Water and Environment Systems 2,1-14; doi:10.13044/j.sdewes.2014.02.0001

Shan, F., Tang, F., Cao, L., \& Fang, G. (2014). Performance evaluations and applications of photovoltaic-thermal collectors and systems. Renewable and Sustainable Energy Reviews. 33, 467-483.doi:10.1016/j.rser.2014.02.018

Toudert, F. A., \& Weidhaus, J., (2017). Numerical assessment and optimization of a low-energy residential building for Mediterranean and Saharan climates using a pilot project in Algeria. Renewable Energy. 101, 327-346; doi:10.1016/j.renene.2016.08.043

Vaishak, S., \& Bhale, P.V. (2019). Photovoltaic/thermal-solar assisted heat pump system: Current status and future prospects.SolarEnergy, 189,268-284. doi:10.1016/j.solener.2019.07.051

(C) 2021. This article is an open access article distributed under the terms and conditions of the Creative Commons Attribution-Share Alike 4.0 (CC BY-SA) International License (http://creativecommons.org/licenses/by- 